\title{
Comparative Studies on Phytochemical Screening and Metal Analysis of Hydro alcoholic Extracts of Beta Vulgaris, Carica Papaya, and Vitis vinifera
}

\author{
Chandaka Madhu' ${ }^{1}$, K Murali Krishna ${ }^{1}$, K Ramanji Reddy*2, Mohammed Omar ${ }^{3}$, SunkaraBhawani ${ }^{1}$ and Sravya $^{* 2}$ \\ Kalakonda ${ }^{1}$ \\ ${ }^{1}$ Department of Pharmacy, MLR Institute of pharmacy, India
}

${ }^{2}$ Department of pharmacy, Startech Labs Pvt Ltd, India

${ }^{3}$ Department of pharmacy, Arya College of Pharmacy, India

Submission: May 12, 2017 ; Published: June 26, 2017

*Corresponding author: K Ramanji Reddy, Sr. Scientist in Startech Labs Pvt Ltd, Department of pharmacy, Startech Labs Pvt Ltd, Madinaguda, Hyderabad,TS-5000050, India, Tel: 9700971895; Email: RAMANJIBIOTECH@GMAIL.COM

\begin{abstract}
The acceptance of remedies in any system of medicine depends upon their efficacy and non-toxicity. There were many reports of rejecting Indian herbal products in various countries because of higher levels of heavy metal content than permitted. Though few are regarded as essential, some heavy metals, especially cadmium, mercury and lead, are potentially hazardous due to their intrinsic or selective toxicity, particularly in environmental contexts.

In view of the importance of herbal drug standardization, it was contemplated to carry out the heavy metal determination in papaya fruits (Carica papaya), grapes (Vitisvinifera) and Beta vulgaris (beet root) which were procured from local market. The metals like copper, iron, magnesium nickel, sodium, potassium, lead, chromium, zinc etc were estimated in the hydro alcoholic extracts by using Atomic Absorption Spectroscopy (AAS). Measurements were made using a hollow Electron Discharge Lamp (EDL). These extracts were also subjected to general phytochemical screening. It's an alarming bell for humankind if the heavy metal content is more than permitted in common edible commodities. Further study may require understanding the factors influencing the heavy metal content in commonly used fruits and vegetables.
\end{abstract}

Keywords: Carica papaya; Vitisvinifera; Beta vulgaris; Atomic Absorption Spectroscopy; Hollow Electron Discharge Lamp

Abbreviations: EDL: Electron Discharge Lamp; AAS: Atomic Absorption Spectroscopy; FDA: Food and Drug Administration; WHO: World Health Organization; UL: Upper Intake Level; DRI: Dietary Reference Intakes

\section{Introduction}

A metal is a word which is derived from Greek called as métallon [1,2]. Metal is a material (an element, compound, or alloy) that is typically hard, opaque, shiny, and has good electrical and thermal conductivity. About 91 of the 118 elements in the periodic table are metals. Metals are mainly divided into five types based upon its nature [3-5]. Some metals adopt both structures depending on the temperature [6] (Table 1). According to IOM recommended guidelines the adequate intake of minerals is given below along with their advantageous and disadvantages [7-22] (Tables 2 \& 3). World health organization currently encourages, recommends and promotes traditional/ herbal preparation in National Health Programmers because such drugs are easily available at low cost, are comparatively safe and the people have faith in such remedies.
Some traditional medicine/herbal preparation with ancient formulas have been found to contain some metals, such as lead, cadmium, mercury, arsenic, lithium etc. Even though the herbal preparations are safe, but some of the herbal preparations cause serious poisoning and toxic effect, due to the preparations containing dangerous toxic drugs or metals. Both medical professional and the general public should be alerted to the potential toxicity of herbal preparation. There should be frequent monitoring of herbal preparations, containing toxic drugs or metals. The objective of the study was to determine the concentration of metals in plants that are used in medicine by the local community. Analysis of the metal in selected plant samples was performed by Atomic Absorption Spectrophotometer (AAS). Measurements were made using a hollow electron 
discharge lamp (EDL) for heavy metals at different wavelengths respectively.

Table 1: Metals adopting both structures depending on the temperature.

\begin{tabular}{|c|c|c|c|}
\hline S.no & $\begin{array}{c}\text { Type of } \\
\text { metals }\end{array}$ & Nature & Example \\
\hline 1 & $\begin{array}{c}\text { Base } \\
\text { metal }\end{array}$ & $\begin{array}{c}\text { Metal that oxidizes or } \\
\text { corrodes relatively easily, and } \\
\text { reacts variably with dilute } \\
\text { hydrochloric acid (HCl) to } \\
\text { form hydrogen }\end{array}$ & $\begin{array}{c}\text { iron, nickel, lead } \\
\text { and zinc }\end{array}$ \\
\hline 2 & $\begin{array}{c}\text { Ferrous } \\
\text { metal }\end{array}$ & $\begin{array}{c}\text { The term "ferrous" is derived } \\
\text { from the Latin word meaning } \\
\text { "containing iron". }\end{array}$ & Iron \\
\hline
\end{tabular}

\begin{tabular}{|c|c|c|c|}
\hline 3 & $\begin{array}{c}\text { Noble } \\
\text { metal }\end{array}$ & $\begin{array}{c}\text { Noble metals are metals that } \\
\text { are resistant to corrosion or } \\
\text { oxidation }\end{array}$ & $\begin{array}{c}\text { gold, platinum, } \\
\text { silver, rhodium, } \\
\text { Iridium and } \\
\text { palladium }\end{array}$ \\
\hline 4 & $\begin{array}{c}\text { Precious } \\
\text { metal }\end{array}$ & $\begin{array}{c}\text { A precious metal is a rare } \\
\text { metallic chemical element } \\
\text { of high economic value. } \\
\text { Chemically, the precious } \\
\text { metals are less reactive than } \\
\text { most elements }\end{array}$ & $\begin{array}{c}\text { Gold, silver, } \\
\text { palladium, } \\
\text { ruthenium, } \\
\text { rhodium, } \\
\text { palladium, } \\
\text { osmium, iridium, } \\
\text { and platinum. }\end{array}$ \\
\hline 5 & $\begin{array}{c}\text { Heavy } \\
\text { metal }\end{array}$ & $\begin{array}{c}\text { A heavy metal is any } \\
\text { relatively dense metal or } \\
\text { metalloid and toxic to the } \\
\text { human body. }\end{array}$ & Arsenic, lead etc \\
\hline
\end{tabular}

Table 2: According to IOM recommended guidelines the adequate intake of minerals along with their advantageous and disadvantages.

\begin{tabular}{|c|c|c|c|c|c|c|c|c|c|c|}
\hline \multicolumn{11}{|c|}{ Recommended adequate intake by the IOM for Minerals mg/day } \\
\hline Age & $\mathrm{Ca}$ & $\begin{array}{c}\mathrm{Cr} \\
\mathrm{mcg} / \\
\text { day }\end{array}$ & $\mathrm{Cu}$ & $\mathrm{Fe}$ & $\begin{array}{c}\mathrm{Pb} \\
\mathrm{Mcg} \\
/ \text { day }\end{array}$ & $\mathrm{Mg}$ & $\mathrm{Ni}$ & K & $\mathrm{Na}$ & $\mathrm{Zn}$ \\
\hline $0-6$ months & 200 & 0.2 & 0.20 & 0.27 & & 30 & & 400 & 120 & 2 \\
\hline 7-12 months & 260 & 5.5 & 0.22 & 11 & & 75 & & 700 & 370 & 3 \\
\hline 1-3years & 700 & 11 & 0.7 & 7 & & 80 & & $3000-4500$ & 1000 & $3-8$ \\
\hline 4-8 years & 1000 & 15 & 1 & 10 & & 130 & & $4500-4700$ & 1200 & 8-11 \\
\hline $9-18$ years & 1300 & 25 & 1.3 & 8 & & 240 & $100-300$ & 4700 & 1500 & 13 \\
\hline $19-50$ years & 1000 & 35 & 1.5 & 11 & & 410 & $400-600$ & & 1500 & \\
\hline 51-70(male) & 1000 & 35 & 1.7 & 8 & & 400 & $500-700$ & & 1500 & \\
\hline 51-70(female) & 1200 & 30 & 1.7 & 8 & & 420 & & & 1200 & \\
\hline $71+$ years & 1200 & & 1.7 & & & & & & -1300 & \\
\hline
\end{tabular}

Table 3: Some traditional medicine/herbal preparation with ancient formulas have been found to contain some metals, such as lead, cadmium, mercury, arsenic, lithium etc.

\begin{tabular}{|c|c|c|c|}
\hline S.No & $\begin{array}{l}\text { Name of } \\
\text { the metal }\end{array}$ & Deficiency & Toxicity \\
\hline 1 & $\mathrm{Ca}$ & $\begin{array}{c}\text { Insomnia, anxiety, nervousness, depression, fatigue, muscle } \\
\text { / joint pains, muscle spasms / cramps, stomach acid, } \\
\text { osteoporosis, seizures, birth defects, miscarriage, high } \\
\text { blood pressure, irregular heartbeat, }\end{array}$ & $\begin{array}{l}\text { Arteriosclerosis, cardiovascular disease, arrhythmia, ischemic } \\
\text { heart disease and stroke, hypertension, low stomach acid, } \\
\text { depression, fatigue, glaucoma, higher risk for several cancers, } \\
\text { muscle / joint pains, osteoporosis, osteoarthritis, calcification, } \\
\text { dry skin, constipation }\end{array}$ \\
\hline 2 & $\mathrm{Cr}$ & $\begin{array}{l}\text { Reduced glucose tolerance / impaired glucose metabolism, } \\
\text { weakened immune system, increased susceptibility for } \\
\text { infections (e.g. bladder, left tonsil), trabecular bone loss, }\end{array}$ & $\begin{array}{c}\text { Spinal / joint degeneration, depressed immune system, } \\
\text { lymphatic swelling }\end{array}$ \\
\hline 3 & $\mathrm{Cu}$ & $\begin{array}{c}\text { Anemia, increased susceptibility for infections, weakened } \\
\text { immune system, hormonal disorders, increased risk } \\
\text { for (colon) cancer, miscarriage, trabecular bone loss, } \\
\text { inflammatory joint disease }\end{array}$ & $\begin{array}{l}\text { Wilson's disease, anemia, nausea, vomiting, abdominal pain, } \\
\text { moodiness, violent behavior, ADD / ADHD, depression, } \\
\text { confusion, weight gain, hemangiomas, arthritis, joint / spinal } \\
\text { degeneration, }\end{array}$ \\
\hline 4 & $\mathrm{Fe}$ & $\begin{array}{l}\text { Fatigue, anemia, depression, dizziness, asthma, } \\
\text { gastrointestinal disorders, pale skin, miscarriage, } \\
\text { amenorrhea (failure to menstruate), dysmenorrhea, } \\
\text { (painful periods), migraine headaches, Ménière's disease, }\end{array}$ & $\begin{array}{l}\text { Hemochromatosis, migraine headaches, arthritis, high } \\
\text { blood pressure, heart disease, liver disease, dizziness, } \\
\text { gastrointestinal disorders, nausea, higher risk for several } \\
\text { cancers, fibroid tumors, benign prostatic hypertrophy (BPH), }\end{array}$ \\
\hline 5 & $\mathrm{~Pb}$ & --- & $\begin{array}{c}\text { lead toxicity is the nervous system, both in adults and } \\
\text { children. damage to the brain and kidneys. reduce fertility, } \\
\text { delayed puberty }\end{array}$ \\
\hline 6 & $\mathrm{Mg}$ & $\begin{array}{c}\text { Irregular heartbeat, cardiovascular disease, anxiety, } \\
\text { insomnia, nervousness, fatigue, muscle / joint pains, } \\
\text { osteoporosis, seizures, high stomach acid, asthma, high } \\
\text { blood pressure, }\end{array}$ & $\begin{array}{c}\text { Cardiovascular disease, arrhythmia, cardiac arrest, coma, } \\
\text { muscle spasms, joint / spinal degeneration, bone loss, low } \\
\text { stomach acid, low body temperature, low blood pressure, } \\
\text { higher risk for several cancers,. }\end{array}$ \\
\hline
\end{tabular}




\begin{tabular}{|c|c|c|c|}
\hline 7 & $\mathrm{Ni}$ & $\begin{array}{l}\text { Hyperglycemia (high blood sugar), low blood pressure, } \\
\text { depression, liver disease, anemia, low stomach acid, sinus } \\
\text { congestion, fatigue, low adrenals }\end{array}$ & $\begin{array}{c}\text { Angina, skin rash, hypoglycemia, decreased estrogen, } \\
\text { shortness of breath, asthma, nausea, lowered pulse, vomiting, } \\
\text { diarrhea, headache, stomach irritation, increased protein in } \\
\text { urine, increased red blood cells, heart failure }\end{array}$ \\
\hline 8 & $\mathrm{~K}$ & $\begin{array}{l}\text { Irregular and/or rapid heartbeat, palpitations, high blood } \\
\text { pressure (hypertension), shortness of breath, asthma, } \\
\text { heart disease, chest pains, stroke, paralysis, muscle } \\
\text { spasms / weakness, bladder weakness, edema (water } \\
\text { retention),kidney disease, }\end{array}$ & $\begin{array}{l}\text { Irregular or slow heart beat, low blood pressure, kidney } \\
\text { disease, cystitis - bladder infections or burning, higher risk of } \\
\text { several types of cancer, infrequent menstrual cycles, muscle } \\
\text { spasms or cramps, ovarian cysts (right), joint / back pains, } \\
\text { weakened immune system, impotence, anxiety, insomnia, } \\
\text { irritability, reactive hypoglycemia, coma. }\end{array}$ \\
\hline 9 & $\mathrm{Na}$ & $\begin{array}{l}\text { Fatigue, depression, mental apathy, low blood pressure, } \\
\text { headaches, dehydration, confusion, dizziness, arthritis, } \\
\text { kidney stones, seizures, In some cases: greater risk for LDL- } \\
\text { related heart disease, high blood pressure, or edema. }\end{array}$ & $\begin{array}{l}\text { Edema, hypertension, stroke, dizziness, gout, headaches, } \\
\text { kidney damage, kidney stones, stomach problems, nausea, } \\
\text { vomiting, coma }\end{array}$ \\
\hline 10 & $\mathrm{Zn}$ & $\begin{array}{l}\text { Decreased growth, loss of taste and smell, sterility, low } \\
\text { sperm count, decreased wound healing, skin rash, hair } \\
\text { loss, heart disease, liver disease, kidney disease, muscle } \\
\text { weakness, enlarged prostate (BPH), several types of cancer, } \\
\text { calcium spurs, paralysis, high blood pressure, arthritis, }\end{array}$ & $\begin{array}{l}\text { Nausea, vomiting, dehydration, stomach ulcers, } \\
\text { gastrointestinal problems, prostatitis, higher risk of several } \\
\text { types of cancer, loss of libido, impotence, joint / back pain, } \\
\text { muscle weakness / cramps, anemia, dysmenorrhea }\end{array}$ \\
\hline
\end{tabular}

\section{Collection and Authentication of Plant Material}

The plant materials CaricaPapaya, Vitisvinifera, and Beta vulgaris were collected in the month of December 2016 from local market in Gandimaisamma, Hyderabad.

\section{Preparation of powder}

The plant material of Carica Papaya, Vitis vinifera, and Beta vulgaris were shade dried and then powdered with a mechanical grinder to form a coarse powder. The powder was passed through sieve no 40 and was stored in an air tight container until further use. The powder was used for the extraction process.

\section{Preparation of Hydroalcholic extract}

Table 4: Phytochemical Screening.

\begin{tabular}{|c|c|c|}
\hline S.NO & PHYTOCHEMICAL & NAME OF THE TEST \\
\hline 1 & Glycosides & Legals test \\
\hline 2 & Saponins & Froth test \\
\hline 3 & Alkaloids & Dragendorffs test \\
\hline 4 & Tannins & Chromic test \\
\hline 5 & Flavoinids & Shinoda test \\
\hline 6 & Mucilage & Ruthenium red test \\
\hline 7 & Carbohydrates & Molisch test \\
\hline 8 & Proteins & Xanthoproteic test \\
\hline 9 & Phytosterols & Salkowski test \\
\hline
\end{tabular}

The hydroalcholic extract of the plant was prepared using Maceration process. The coarse powder of plant (500g) was taken in a beaker with the water $(70 \%)$ and ethanol (30\%) quantity of $1000 \mathrm{ml}$ and was macerated for $72 \mathrm{hrs}$. During the Maceration occasional stirring were carried out. After 72 hrs, the suspension was filtered through a fine muslin cloth. The solvent was removed by heating until residues was obtained and then calculate the percentage yield (Table 4 ).

\section{Preparation of Extract Sample}

$1 \mathrm{~g}$ of the extract was weighed and transferred into $50 \mathrm{ml}$ of beaker. Then add $5 \mathrm{ml}$ of conc. $\mathrm{HNO}_{3}$ and placed on hot plate until the organic fumes were completely stopped. Then add 25 $\mathrm{ml}$ of water for acid digestion on hot plate. Digestion to be taken until $50 \%$ of the sample was too evaporated and remaining sample was filtered and makeup to $25 \mathrm{ml}$, and gone for furthered dilutions.

\section{Preparation of standard}

The standard reagent $1000 \mathrm{ppm}$ was purchased from The National Institute of Standards and Technology (NIST) from Pune. From the standard reagent bottles (1000 ppm), they were furthered diluted to $0.5,1,1.5 \mathrm{ppm}$. Select the position of Hallow Discharged Lamp which are placed in the socket (capacity of the socket is max 6 lamps only). Blank, Standards (0.5, 1, 1.5ppm), Blank and Sample were aspirate into AAS.

\section{Calculation}

The amount metals $(\mathrm{ppm})=$ conc of the test $\mathrm{X}$ dilution factor / weight of the test taken.

\section{Results and Discussions}

(Tables 5-10), (Figures 1-11).

Table 5: Percentage yield of the extract.

\begin{tabular}{|c|c|c|}
\hline S.No & Name of The Plant & Percentage Yield (\%) \\
\hline 1 & Carica papaya & $3.6 \%$ \\
\hline 2 & Vitis vinifera & $4.6 \%$ \\
\hline 3 & Beta vulgaris & $3.4 \%$ \\
\hline
\end{tabular}

Table 6: Phytochemical screening.

\begin{tabular}{|c|c|c|c|c|c|c|c|c|c|}
\hline $\begin{array}{c}\text { Name of } \\
\text { the plant }\end{array}$ & Alk & Carb & Gly & Tan & Phytos & Flav & sapo & Pro & muci \\
\hline $\begin{array}{c}\text { Carica } \\
\text { papaya }\end{array}$ & + & + & + & + & + & -- & -- & + & -- \\
\hline $\begin{array}{c}\text { Vitis } \\
\text { vinifera }\end{array}$ & + & + & + & + & + & + & + & + & -- \\
\hline $\begin{array}{c}\text { Beta } \\
\text { vulgaris }\end{array}$ & + & + & + & + & + & + & - & -- & + \\
\hline
\end{tabular}


Table 7: Estimation of metals.

\begin{tabular}{|c|c|c|c|c|c|c|c|}
\hline Socket & Element & Lamp type & Lamp id & Judge & Life time & Used time & Units \\
\hline 1 & $\mathrm{Zn}$ & Normal & $\mathrm{Zn}-1$ & Ok & 5000 & 266.5 & $\mathrm{~mA}^{*} \mathrm{hrs}$ \\
\hline 2 & $\mathrm{Cu}$ & Normal & $\mathrm{Cu}-1$ & $\mathrm{Ok}$ & 5000 & 277.0 & $m A^{*}$ hrs \\
\hline 3 & $\mathrm{Ni}$ & Normal & $\mathrm{Ni}-1$ & $\mathrm{Ok}$ & 5000 & 166.4 & $\mathrm{~mA}^{*} \mathrm{hrs}$ \\
\hline 4 & $\mathrm{Cr}$ & Normal & $\mathrm{Cr}-1$ & $\mathrm{Ok}$ & 5000 & 112.7 & $m A^{*}$ hrs \\
\hline 5 & $\mathrm{~Pb}$ & Normal & $\mathrm{Pb}-1$ & Ok & 5000 & 303.3 & $\mathrm{~mA}^{*} \mathrm{hrs}$ \\
\hline 6 & $\mathrm{Ca}$ & Normal & $\mathrm{Ca}-1$ & Ok & 5000 & 382.6 & $m A^{*}$ hrs \\
\hline 7 & $\mathrm{Na}$ & Normal & $\mathrm{Na}-1$ & $\mathrm{Ok}$ & 5000 & 516.1 & $\mathrm{~mA}^{*} \mathrm{hrs}$ \\
\hline 8 & $\mathrm{Mg}$ & Normal & $\mathrm{Mg}-1$ & Ok & 5000 & 451.5 & $\mathrm{~mA}^{*} \mathrm{hrs}$ \\
\hline 9 & K & Normal & $\mathrm{K}-1$ & Ok & 5000 & 340.0 & $\mathrm{~mA}^{*} \mathrm{hrs}$ \\
\hline 10 & $\mathrm{Fe}$ & Normal & $\mathrm{Fe}-1$ & $\mathrm{Ok}$ & 5000 & 719.5 & $\mathrm{~mA}^{*} \mathrm{hrs}$ \\
\hline
\end{tabular}

Table 8: Weight of the extract taken for acid digestion.

\begin{tabular}{|c|c|c|}
\hline S. No & Name of the extract & Weight taken \\
\hline 1 & Carica papaya & $1.069 \mathrm{G}$ \\
\hline 2 & Vitis vinifera & $1.054 \mathrm{G}$ \\
\hline 3 & Beta vulgaris & $1.0512 \mathrm{G}$ \\
\hline
\end{tabular}

Table 9: Parameters of Metal Analysis in Aas-6300 Model.

\begin{tabular}{|c|c|c|c|c|c|c|c|c|c|c|}
\hline \multicolumn{11}{|c|}{ Parameters of AAS for each metals } \\
\hline Element & $\mathbf{Z n}$ & $\mathrm{Ni}$ & $\mathrm{Fe}$ & $\mathbf{K}$ & Mg & $\mathrm{Na}$ & $\mathrm{Ca}$ & $\mathbf{P b}$ & $\mathrm{Cr}$ & $\mathrm{Cu}$ \\
\hline Wavelength & 213.9 & 232.0 & 248.3 & 766.5 & 285.2 & 589.0 & 422.7 & 283.3 & 357.9 & 324.8 \\
\hline Peak (nm) & 213.87 & 232.47 & 248.43 & 766.55 & 285.07 & 588.76 & 422.60 & 283.23 & 358.00 & 324.67 \\
\hline Lamp current low(ma) & 8 & 12 & 12 & 10 & 8 & 12 & 10 & 10 & 10 & 6 \\
\hline Slit width (nm) & 0.7 & 0.2 & 0.2 & 0.7 & 0.7 & 0.2 & 0.7 & 0.7 & 0.7 & 0.7 \\
\hline Lamp mode & BGC-D2 & BGC-D2 & BGC-D2 & NON-BGC & BGC-D2 & NON-BGC & BGC-D2 & BGC-D2 & BGC-D2 & BGC-D2 \\
\hline Line search & $\mathrm{Ok}$ & $\mathrm{Ok}$ & Ok & Ok & $\mathrm{Ok}$ & $\mathrm{Ok}$ & Ok & Ok & $\mathrm{Ok}$ & $\mathrm{Ok}$ \\
\hline Beam balance & $\mathrm{Ok}$ & $\mathrm{Ok}$ & $\mathrm{Ok}$ & $\mathrm{Ok}$ & $\mathrm{Ok}$ & $\mathrm{Ok}$ & $\mathrm{Ok}$ & $\mathrm{Ok}$ & $\mathrm{Ok}$ & $\mathrm{Ok}$ \\
\hline
\end{tabular}

Table 10: Metal Concentration in Ppm Level in Plant Extract by Using Aas.

\begin{tabular}{|c|c|c|c|c|}
\hline \multicolumn{5}{|c|}{ Comaprative Study of Metal Analysis } \\
\hline S.no & Elements & $\begin{array}{c}\text { Beta vulgaris } \\
\text { (ppm) }\end{array}$ & $\begin{array}{c}\text { Carica papaya } \\
\text { (ppm) }\end{array}$ & $\begin{array}{c}\text { Vitis vinifera } \\
\text { (ppm) }\end{array}$ \\
\hline 1 & Zinc & 20.29 & 18.25 & 7.239 \\
\hline 2 & Copper & 3.629 & 2.82 & 23.70 \\
\hline 3 & Nickel & 1.812 & 1.075 & 1.20 \\
\hline 4 & Chromium & 0.980 & 1.131 & 1.704 \\
\hline 5 & Lead & 13.40 & 4.080 & 6.33 \\
\hline 6 & Calcium & 76.12 & 96.12 & 55.27 \\
\hline 7 & Sodium & 45.69 & 42.37 & 3.57 \\
\hline 8 & Magnesium & 8.835 & 9.241 & 10.73 \\
\hline 9 & Potassium & 9.141 & 10.139 & 6.34 \\
\hline 10 & Iron & 29.31 & 17.30 & 12.64 \\
\hline \multicolumn{5}{|c|}{} \\
\hline
\end{tabular}

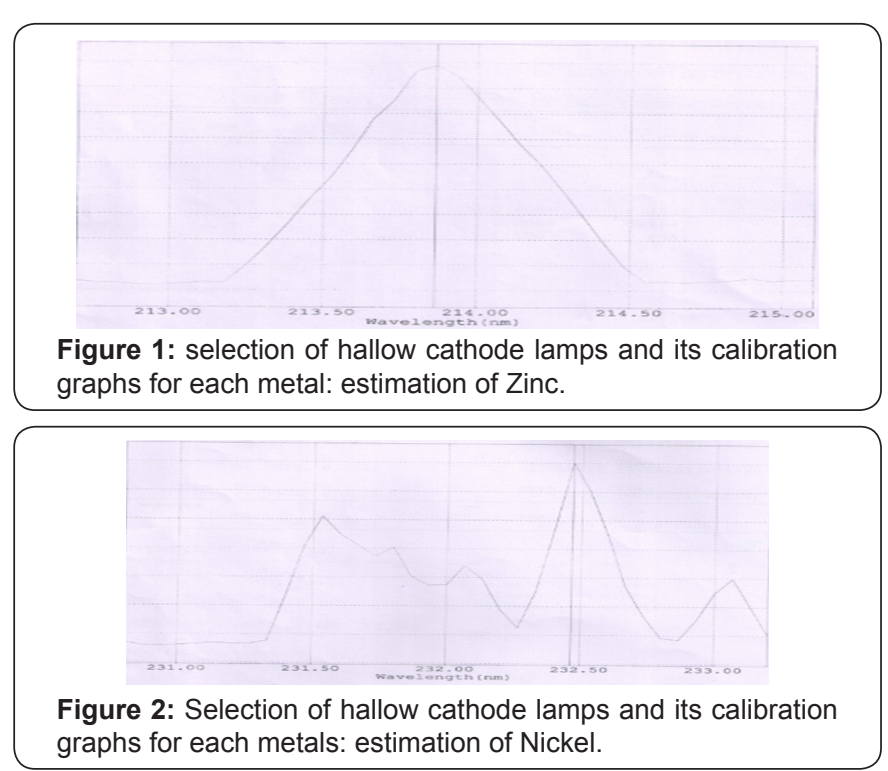




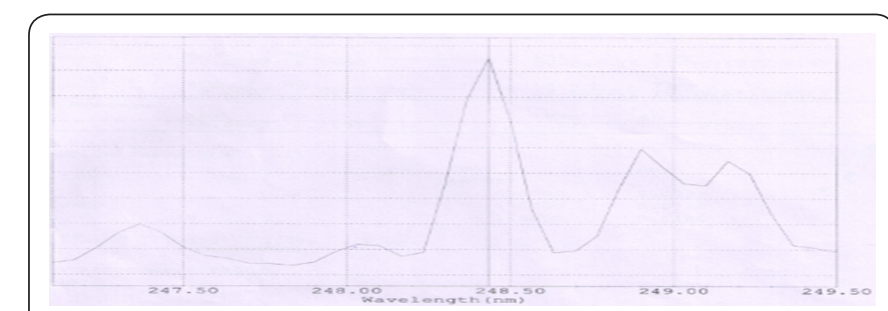

Figure 3: Selection of Hallow Cathode Lamps and Its Calibration Graphs for Each Metals: estimation of Iron.

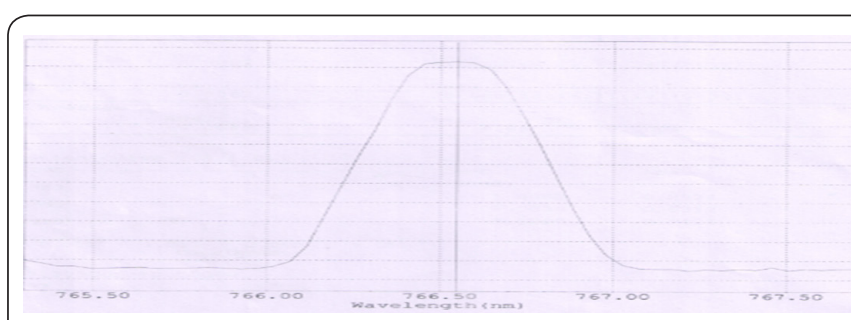

Figure 4: Selection Of Hallow Cathode Lamps and Its Calibration Graphs for Each Metals: estimation of Potassium.

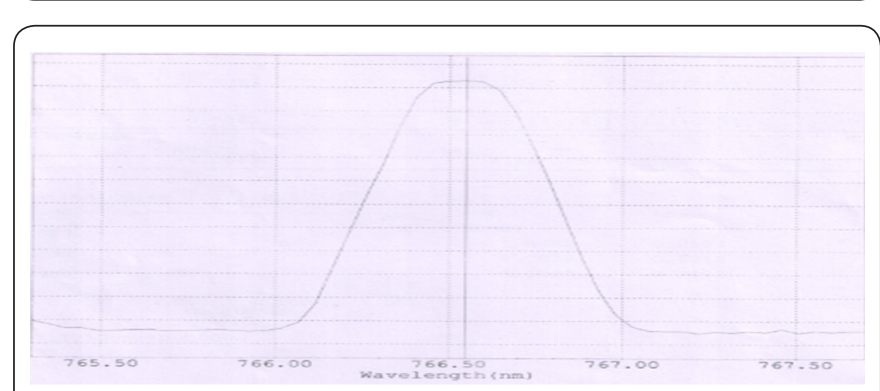

Figure 5: Selection of Hallow Cathode Lamps and Its Calibration Graphs for Each Metals: estimation of Magnesium.

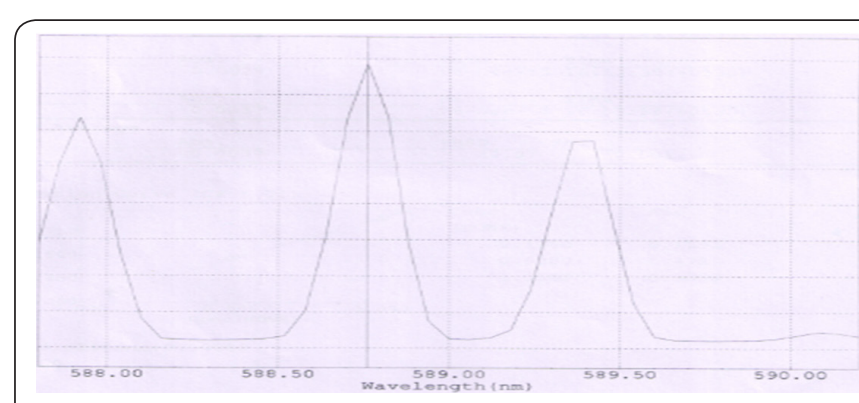

Figure 6: Selection of Hallow Cathode Lamps and Its Calibration Graphs for Each Metals: estimation of Sodium.

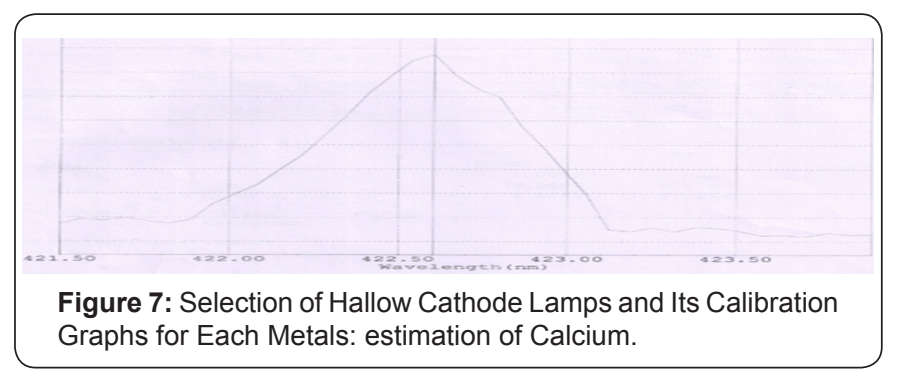
Figure 7: Selection of Hallow Cathode Lamps and Its Calibration
Graphs for Each Metals: estimation of Calcium.

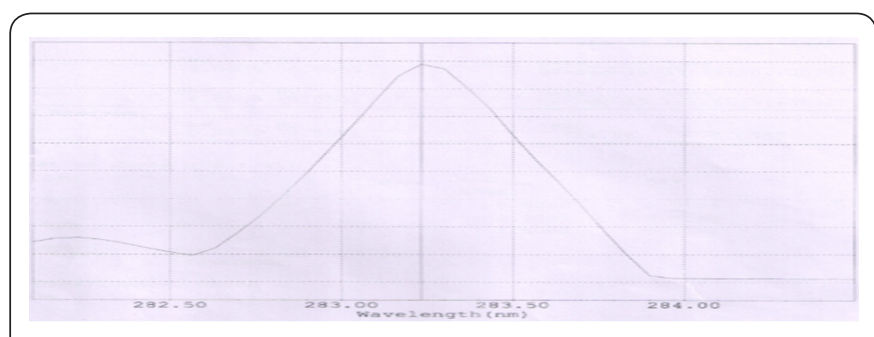

Figure 8: Selection of Hallow Cathode Lamps and Its Calibration Graphs for Each Metals: estimation of Lead.

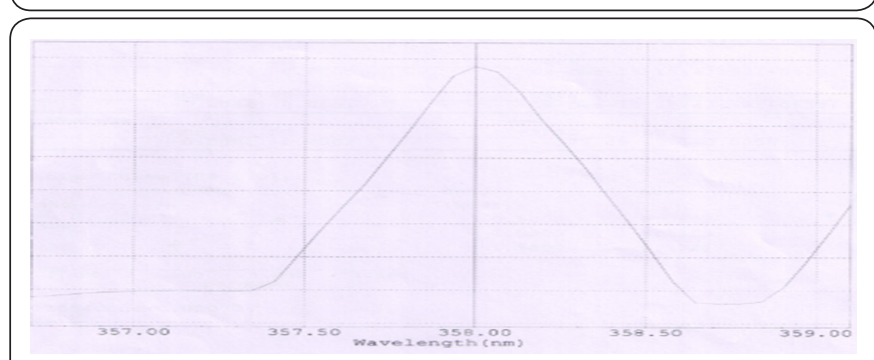

Figure 9: Selection of Hallow Cathode Lamps and Its Calibration Graphs for Each Metals: estimation of Chromium.

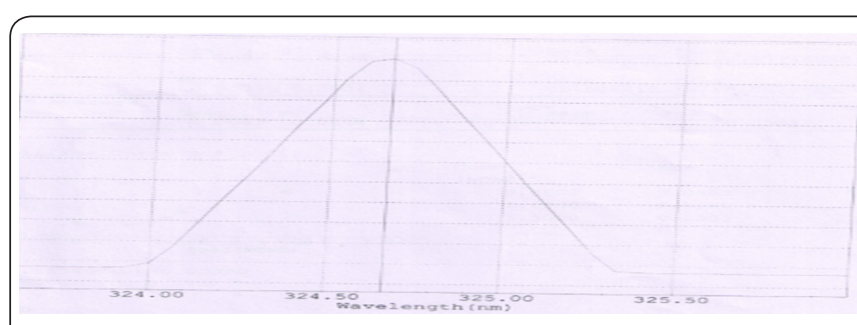

Figure 10: Selection of Hallow Cathode Lamps and Its Calibration Graphs for Each Metals: estimation of Copper.

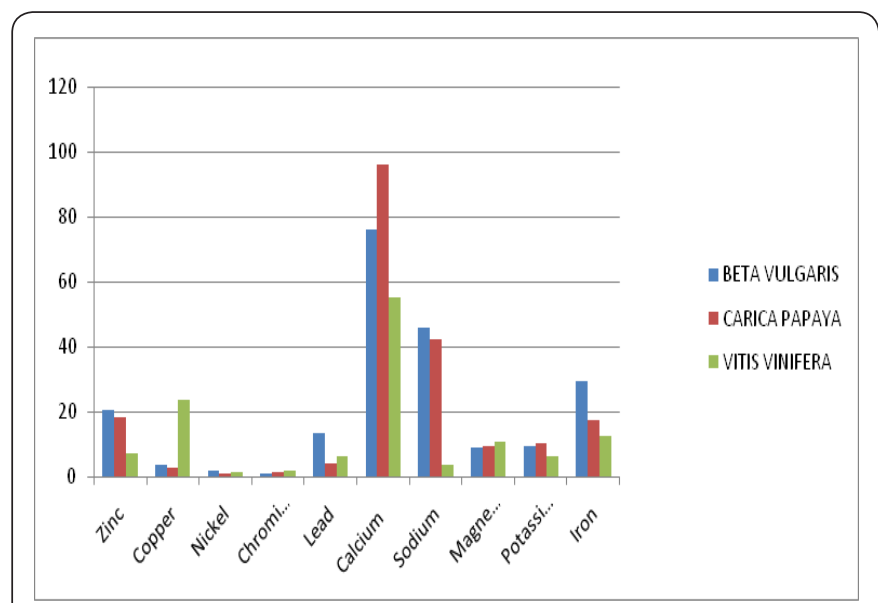

Figure 11: Comparative study of Metal Analysis.

\section{Conclusion}

The hydroalcholoic extracts of Carica papaya, Vitisvinifera and Beta vulgaris were prepared and their percentage yields in ascending order are Beta vulgaris (3.4\%), Carica papaya (3.6\%) and Vitisvinifera (4.6\%).

These extracts were subjected to preliminary phytochemical screening and Caricapapaya extract consists of alkaloids, 
carbohydrates, glycosides, tannins, phytosterols, proteins, and mucilage. Vitisvinifera extract was found to contain alkaloids, carbohydrates, glycosides, tannins, phytosterol, flavanoids , saponins and proteins. AlkaloIds, carbohydrates, glycosides, tannins, phytosterol, flavanoids, and mucilage were present in Beta vulgaris extract. AAS can be employed to determine over 70 different elements in solution or directly in solid samples and has wide application in the fields of pharmacology, biophysics and toxicology research. In our present study, we have estimated the metals like Zinc, Copper, Nickel, Chromium, Lead Calcium, Sodium, Magnesium, Potassium and Iron in the extracts of Carica papaya, Vitisvinifera and Beta vulgaris.

\section{Zinc}

Zinc is an essential trace element for humans, animals, microorganisms and for plants. It is the second most abundant transition metal in organisms after iron. Most zinc is in the brain, muscle, bones, kidney, and liver, with the highest concentrations in the prostate and parts of the eye. It is the only metal which appears in all enzyme classes and found in nearly 100 specific enzymes. It is considered as of "exceptional biologic and public health importance", especially regarding prenatal and postnatal development. Semen is particularly rich in zinc, which is a key factor in prostate gland function and reproductive organ growth.

Symptoms of mild zinc deficiency include depressed growth, diarrhea, impotence and delayed sexual maturation, alopecia, impaired appetite, and reproductive teratogenesis etc. The U.S. Food and Drug Administration (FDA) have stated that zinc damages nerve receptors in the nose, which can cause anosmia. Excess zinc can be harmful, and cause zinc toxicity to occur at ingestion of greater than $225 \mathrm{mg}$ of Zinc. Excessive absorption of zinc can suppress copper and iron absorption. The U.S. Food and Drug Administration (FDA) have stated that zinc damages nerve receptors in the nose, which can cause anosmia.

Tolerable Upper Intake Level UL: 4mg -40mg. Our experiments revealed that zinc was present at $20.29 \mathrm{ppm}$ in Beta vulgaris, $18.25 \mathrm{ppm}$ in Carica papaya and $7.239 \mathrm{ppm}$ in Vitisvinifera levels in these extracts. These levels of zinc are far lower than the toxicity level.

\section{Calcium}

Calcium is essential for living organisms, in particular in cell physiology, where movement of the calcium ion into and out of the cytoplasm functions as a signal for many cellular processes. As a major material used in mineralization of bone, teeth and shells, calcium is the most abundant metal by mass in many animals. Symptoms of hypocalcaemia include numbness and tingling in the fingers, muscle cramps, convulsions, lethargy, poor appetite, and abnormal heart rhythms if left untreated, calcium deficiency leads to death. Inadequate calcium intake causes osteopenia which if untreated can lead to osteoporosis. The risk of bone fractures also increases, especially in older individuals.
Excessive consumption of calcium carbonate antacids/ dietary supplements (such as Tums) over a period of weeks or months can cause milk-alkali syndrome, with symptoms ranging from hypercalcemia to potentially fatal renal failure. Persons consuming more than 10 grams/day of $\mathrm{CaCO}_{3}(=4 \mathrm{~g} \mathrm{Ca})$ are at risk of developing milk-alkali syndrome, Tolerable Upper Intake Level UL of calcium is: $1000 \mathrm{mg}-3000 \mathrm{mg}$. The experimental results indicated that $76.12 \mathrm{ppm}$ in Beta vulgaris, $96.12 \mathrm{ppm}$ in Carica papaya and 55.27ppm in Vitisvinifera were present. Therefore the levels of calcium present in these three tested samples are safe and give only beneficial effects.

\section{Iron}

Iron is a necessary trace element found in nearly all living organisms. Iron-containing enzymes and proteins, often containing heme prosthetic groups, participate in many biological oxidations and in transport. The World Health Organization (WHO) estimates that approximately half of the 1.62 billion cases of anemia worldwide are due to iron deficiency. Large amounts of ingested iron can cause excessive levels of iron in the blood. High blood levels of free ferrous iron react with peroxides to produce free radicals, which are highly reactive and can damage DNA, proteins, lipids, and other cellular components. Thus, iron toxicity occurs when there is free iron in the cell, which generally occurs when iron levels exceed the capacity of transfer in to bind the iron. Tolerable Upper Intake Level UL: $40 \mathrm{mg}-45 \mathrm{mg}$. The experimental results indicated that 29.31 ppm in Beta vulgaris, 17.30 ppm in Carica papaya and 12.64 ppm in Vitisvinifera were present. These provide beneficial effects and do not cause any toxicity.

\section{Copper}

Numerous antimicrobial efficacy studies have been conducted in the past 10 years regarding copper's efficacy to destroy a wide range of bacteria, as well as influenza a virus, adenovirus, and fungi. Copper is also found in many superoxide dismutases, proteins that catalyze the decomposition of superoxide's, by converting it (by disproportionate) to oxygen and hydrogen peroxide: Deficiency of copper in animals has resulted in anemia, osteoporosis, delayed wound healing and the development of aortic aneurysms, and loss of hair color. Acute copper toxicity, such as that following the ingestion of more than $15 \mathrm{mg}$ of elemental copper, has been associated with nausea, vomiting, diarrhea, and intestinal cramps. Intravascular hemolysis has occurred with larger ingestions. Tolerable Upper Intake Level UL: $1 \mathrm{mg}-10 \mathrm{mg}$. The experimental results indicated that $3.629 \mathrm{ppm}$ in Beta vulgaris, $2.82 \mathrm{ppm}$ in Carica papaya and 23.70 ppm in Vitis vinifera were present. The amounts are within the limits.

\section{Chromium}

Humans require chromium in trace amounts, although its mechanisms of action in the body and the amounts needed for optimal health are not well defined Chromium is known 
to enhance the action of insulin, a hormone critical to the metabolism and storage of carbohydrate, fat, and protein in the body. Few serious adverse effects have been linked to high intakes of chromium, so the Institute of Medicine has not established a Tolerable Upper Intake Level (UL) for this mineral. A UL is the maximum daily intake of a nutrient that is unlikely to cause adverse health effects. It is one of the values (together with the RDA and AI) that comprise the Dietary Reference Intakes (DRIs) for each nutrient. Tolerable Upper Intake Level: $200 \mathrm{mcg}$ $-5,000 \mathrm{mcg}$. The experimental results indicated that $0.980 \mathrm{ppm}$ in Beta vulgaris 1.131 ppm in Carica papaya and 1.704 ppm in Vitis vinifera was present. The quantities are in safe limits.

\section{Nickel}

Nickel plays important roles in the biology of microorganisms and plants. Plant enzyme urease (an enzyme that assists in the hydrolysis of urea) contains nickel. Nickel deficiency causes hyperglycemia (high blood sugar), low blood pressure, depression, liver disease, anemia, low stomach acid, sinus congestion, fatigue, low adrenals. Tolerable Upper Intake Level UL: 200 mcg $-1,000$ mcg. Most of the nickel absorbed every day by humans is removed by the kidneys and passed out of the body through urine or is eliminated through the gastrointestinal tract without getting absorbed. Nickel is not a cumulative toxicant; however, larger doses or chronic exposure may be dangerous for human health and may represent an occupational hazard due to their acute toxicity and carcinogenicity. Tolerable Upper Intake Level UL: $200 \mathrm{mcg}-1,000 \mathrm{mcg}$. The experimental results indicated that $1.812 \mathrm{ppm}$ in Beta vulgaris $1.075 \mathrm{ppm}$ in Carica papaya and $1.20 \mathrm{ppm}$ in Vitis vinifera was present. The amounts of nickel are well within the UL values therefore safe to consume.

\section{Potassium}

Potassium levels influence multiple physiological processes Resting cellular-membrane potential and the propagation of action potentials in neuronal, muscular, and cardiac tissue. Potassium Deficiency causes irregular and/or rapid heartbeat, palpitations, high blood pressure (hypertension), shortness of breath, asthma, heart disease, chest pains, stroke, paralysis, muscle spasms / weakness, bladder weakness, edema (water retention), kidney disease, liver disease, endometriosis, frequent menstrual cycles, high blood sugar, weight gain, fatigue, impotence. Tolerable Upper Intake Level UL: 300mg $-15,000 \mathrm{mg}$. The experimental results indicated that $9.141 \mathrm{ppm}$ in Beta vulgaris $10.139 \mathrm{ppm}$ in Carica papaya and $6.34 \mathrm{ppm}$ in Vitis vinifera was present. Our estimation of potassium revealed that the amounts of potassium are well within the UL values therefore safe to consume.

\section{Sodium}

In humans, sodium is an essential nutrient that regulates blood volume, blood pressure, osmotic equilibrium and $\mathrm{pH}$; the minimum physiological requirement for sodium is 500 milligrams per day. 50 Sodium chloride is the principal source of sodium in the diet, and is used as seasoning. Sodium deficiency leads to fatigue, depression, mental apathy, low blood pressure, headaches, dehydration, confusion, dizziness, arthritis, kidney stones, seizures, in some cases: greater risk for LDL-related heart disease, high blood pressure, or edema. Tolerable Upper Intake Level UL: 1,500mg -2,300mg. Excess sodium intake leads to edema, hypertension, stroke, dizziness, gout, headaches, kidney damage, kidney stones, stomach problems, nausea, vomiting, coma

The experimental results indicated that $45.69 \mathrm{ppm}$ in Beta vulgaris 1. 42.37 ppm in Carica papaya and 3.57 ppm in Vitis vinifera were present. The results proved that amounts of sodium are well within the UL valus therefore safe to consume.

\section{Magnesium}

Magnesium deficiency (hypomagnesaemia) is common: and found in $2.5-15 \%$ of the general population. The primary cause of deficiency is decreased dietary intake: Other causes are increased renal or gastrointestinal loss, an increased intracellular shift, and proton-pump inhibitor antacid therapy. Health Risks from Excessive Magnesium Too much magnesium from food does not pose a health risk in healthy individuals because the kidneys eliminate excess amounts in the urine. Tolerable Upper Intake Level UL: $65 \mathrm{mg}-360 \mathrm{mg}$. The experimental results indicated that $8.835 \mathrm{ppm}$ in Beta vulgaris 1. $9.241 \mathrm{ppm}$ in Carica papaya and10.73ppm in Vitis vinifera was present. Overdose from dietary sources alone is unlikely because excess magnesium in the blood is promptly filtered by the kidneys.

\section{Lead}

Lead is a highly poisonous metal (whether inhaled or swallowed), affecting almost every organ and system in the body. The component limit of lead $(1.0 \mu \mathrm{g} / \mathrm{g})$ is a test benchmark for pharmaceuticals, representing the maximum daily intake an individual should have. However, even at this low level, a prolonged intake can be hazardous to human beings. Recommended not more than: The component limit of lead (1.0 $\mu \mathrm{g} / \mathrm{g}$ ). Our experimental results indicated that $13.40 \mathrm{ppm}$ in Beta vulgaris 4.080 ppm in Carica papaya and6.33 ppm in Vitis vinifera was present. In consideration with reported lead toxicity with many herbal preparations and rejections of exports from India by many countries particularly the US, emphasis is given on lead amounts. . The maximum limit of lead in Beta vulgaris is more than permitted. However before drawing a conclusion from the results, it is to be assessed carefully based on the areas of cultivation, the effect of industrial pollution and utilization of large samples.

\section{References}

1. Henry George Liddell, Robert Scott (1940) A Greek-English Lexicon, on Perseus Digital Library, Oxford, clarendon press, England, UK.

2. Metal on Oxford Dictionaries, Oxford University Press, UK.

3. Metals and Minerals Mission 2007-2014 
4. Mortimer, Charles E (1975) Chemistry: A Conceptual Approach $\left(3^{\text {rd }}\right.$ edn), D Van Nostrad Company, New York, USA.

5. Frank Kreith, Yogi Goswami eds (2004) The CRC Handbook of Mechanical Engineering, (2 ${ }^{\text {nd }}$ edn), Boca Raton, USA, p. 12-22.

6. Holleman AF, Wiberg E (2001) "Inorganic Chemistry" Academic Press, USA.

7. Egbuna Ogo I, Bose Anirban (2004) "Acute Aluminum Neurotoxicity Secondary To Treatment Of Severe Hyperphosphatemia Of Acute Renal Failure And The K/DOQI Guidelines: A Case Report And Review Of The Literature". The Internet Journal of Nephrology 2(2): 4.

8. Chugh SN, Dushyant, Ram S, Arora B, Malhotra KC (1991) "Incidence \& outcome of aluminium phosphide poisoning in a hospital study". The Indian journal of medical research 94: 232-235.

9. Singh S, Singh D, Wig N, Jit I, Sharma BK, et al. (1996) "Aluminum phosphide ingestion-a clinico-pathologic study". Journal of Toxicology Clinical Toxicology 34 (6): 703-706.

10. Mathai Ashu, Bhanu Madhurita singh (2010) "Acute aluminium phosphide poisoning: Can we predict mortality?" Indian Journal of Anaesthesia 54(4): 302-307.

11. A Wahab, MS Zaheer, S Wahab, RA Khan (1940) "Acute aluminium phosphide poisoning: an update" Hong Kong Journal of Emergency Medicine: 152.

12. Siwach SB, Gupta A (1995) "The profile of acute poisonings in Harayana-Rohtak Study". J Assoc Physicians India 43(11): 756-759.

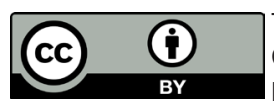

This work is licensed under Creative

Commons Attribution 4.0 Licens

DOI: 10.19080/JOJPH.2017.02.555582
13. "Arsenic in drinking water seen as threat (2007) USA Today, USA.

14. Peter Ravenscroft (2007) "Predicting the global distribution of arsenic pollution in groundwater." Paper presented at: "Arsenic- The Geography of a Global Problem," Royal Geographic Society Arsenic Conference held at: Royal Geographic Society, London, England, UK.

15. "IARC Monograph" (1993) International Agency for Research on Cancer 58.

16. "Safety and Health Topics | Cadmium" (2013).

17. "Plants Poisonous to Livestock - Cornell University Department of Animal Science" (2012).

18. Tenenbein Milton (2005) "Unit-Dose Packaging of Iron Supplements and Reduction of Iron Poisoning in Young Children". Arch Pediatr Adolesc Med 159(6): 557-560.

19. AAPCC Annual Reports, American Association of Poison Control Centers.

20. Markowitz Glen S, Radhakrishnan Jai, Kambham Neeraja, Valeri Anthony M, Hines William H, et al. (2000) "Lithium Nephrotoxicity: A Progressive Combined Glomerular and Tubulointerstitial Nephropathy". J Am Soc Nephrol 11 (8): 1439-1448.

21. Couper J (1837) "Sur les effets du peroxide de manganèse". Journal de chimiemédicale, de pharmacie et de toxicologie 3: 223-225.

22. James William D, Berger Timothy G, Elston Dirk M, Odom Richard B (2006) Andrews' diseases of the skin: clinical dermatology. Saunders Elsevier, USA, pp. 858.

\section{Your next submission with Juniper Publishers will reach you the below assets}

- Quality Editorial service

- Swift Peer Review

- Reprints availability

- E-prints Service

- Manuscript Podcast for convenient understanding

- Global attainment for your research

- Manuscript accessibility in different formats

( Pdf, E-pub, Full Text, Audio)

- Unceasing customer service

Track the below URL for one-step submission https://juniperpublishers.com/online-submission.php 